\title{
People of the Church as Reflected in Contemporary Polish surnames
}

\author{
Justyna B. Walkowiak \\ Adam Mickiewicz University in Poznań, Poland
}

\begin{abstract}
Many contemporary Polish surnames motivated by religion are derived from church or monastery positions. Catholicism, dominant in Poland, requires celibacy of clergy and monks; therefore, surnames like Biskup 'bishop', Mnich 'monk' and Proboszcz 'parish priest' developed mostly from nicknames, not as occupational surnames. This finds additional evidence in the high frequency of such surnames as Papie $\dot{z}$ 'the Pope' and its variants. Nevertheless, certain surnames, e.g. Kantor '(church/synagogue) singer' or Kościelny 'sacristan', reflect church functions performed by non-celibate laymen. The surnames are discussed with respect to their possible origin, semantics and statistics, including positions in other religions alongside Catholic hierarchy.
\end{abstract}

Keywords: surnames, church hierarchy, Christianity.

\section{Introduction}

Polish surnames include at present, it is estimated, at least 400 thousand different onyms (Rymut 1999: VI). Among these, some are occupational in origin. While it is difficult to establish their percentage in the overall anthroponomasticon, it can safely be estimated that among the thousand most frequent ones in contemporary Poland they constitute approximately one seventh. However, only several of these are ecclesiastical occupational surnames, i.e. those motivated by the names of church or monastery positions.

According to the nature of the motivating relationship that presumably used to bind a particular church-related nickname (from which later a surname developed) with its bearer, two types may be distinguished: names which may have referred to the actual profession, such as Kościelny (cf. the Polish appellative kościelny 'sacristan, sexton'), Oblacewicz (cf. oblat 'oblate') or Psalmister (cf. psalmista 'author of psalms' or in Orthodox Christianity 'singer of psalms'), and those in which the profession motivating the nickname that later developed into a surname cannot have been treated literally, a striking case in point being the surname Papiez (cf. the appellative papie $\dot{z}$ 'the Pope') and its numerous derivatives. Tomczak (1992: 130) gives an example of a contemporary nickname of a village dweller, Wikary, motivated by the fact that his brother for many years used to be merely a vicar, never a parish priest.

It must be borne in mind that the predominant religion in the ethnically Polish 
areas of the Polish-Lithuanian Commonwealth used to be (and both in Poland and Lithuania still is) Catholicism ${ }^{1}$. This fact, coupled with the official celibacy of the Catholic clergy, which was made legally binding by Pope Innocent III (1198-1216), indicates that the names of most church functions as motivation for nicknames should probably be understood metaphorically.

On the other hand, caution must be exercised. In what follows, the aforementioned division into literally and metaphorically construed nicknames/surnames will not be followed too strictly. First, some church positions that in contemporary Poland are obviously clergy turf, were once available to laymen as well. Jan Kochanowski, the most famous Polish Renaissance poet, was at one point in his life a prepozyt, proboszcz ('parish priest') without having being ordained; he only had to resign when he decided to marry. However, his duties were of administrative nature and he did not celebrate Mass. Second, the practice diverged from the officially declared celibate, and even in late Middle Ages some priests did have wives ${ }^{2}$. As E.C. Smith (1986: 130-131) noted,

There are many surnames which seem to indicate that a remote ancestor was an official of the Church who performed sacerdotal functions, and this may appear puzzling in view of the rule of celibacy enjoined on its ministers by the Catholic Church. Notwithstanding the inflexible rule of the Church against marriage by its clergy, many were married in medieval times. There were instances where the last representative of an ancient family obtained from the Pope a dispensation to marry upon the death of an older brother or other relative whereby his family was in danger of becoming extinct. It was not an uncommon thing in the Middle Ages for widowers to go into the Church, a significant act which might affect the names of their children at the times surnames were becoming hereditary [...]. Particularly before the Norman conquest, clerical marriages were quite common. Efforts to abolish them were only partially successful especially in the north of England [...]. Several of the bishops of Durham and at least one archbishop of York had children. Besides the clergy who were formally married there were many who had consorts or hearth-mates. Children of such unions would not be scorned and would be known in the community by a sobriquet referring to their clerical father.

1 Reformation in Poland, with its three chronologically successive movements (Lutheranism, Calvinism and an antitrinitarian wing of the Calvinists called Polish Brethren) and its culmination in the second half of the $16^{\text {th }}$ century, was relatively transient. It was also markedly elitist: the Calvinists were mostly members of the landed gentry, while Lutherans were found chiefly among the burghers of the Duchy of Prussia and on the territories adjacent to its border, as well as in Courland and in most of Swedish Livonia. Reformation never gained ground among peasants.

2 “The Council [of Trent, 1545-1563] received a report that 96 per cent of Bavarian priests had concubines or clandestine wives. An Austrian inspector in 1563 found a typical monastery to be composed of nine monks, seven concubines, two 'wives', and eight children. In 1542, Archbishop Albrecht of Brandenburg admitted to a papal representative that all his priests were living in concubinage, but they would become Lutherans if he tried to do something about it" (Phipps 2004: 160). 


\section{Church hierarchy}

The Polish name of the head of the Catholic church, papiez 'the Pope', is reflected in a number of surnames: Papież 21873, Papieżyński 25, Papieżański 2, Popież 10, Popierz 49, Popiesz 18, Papierz 1565, Papierzański 60, Papierzewski 18, Papierzyński 233, Papiesz 17, Papies 11. One could add to these two more names, Papiewski 569 and Papieski 85, according to Rymut (2001: 206) both toponymic (cf. Papieze, a village in central Poland, Piotrków County), as well as the German Papst 61. Just like similar surnames in other European languages - e.g. German Papst, Pabst, Pape, Pfaff, Italian Papa, English Pope (sometimes spelled Pape), Spanish Papa, Hungarian Papp/Pap and many more - this name, first attested in Poland in 1382 (in the form Papezs, later also spelled Papesz, Papyesz, Papyesch, Papiesch, Papiesz, cf. SSNO IV: 187), probably derives from a nickname given to someone playing the part of the pope in a medieval pageant or play, or maybe to someone ascetic-looking or ostentatiously pious. That the surname may once have been perceived as blasphemous is evidenced by the fact that at the beginning of the $19^{\text {th }}$ century Magdalena Maria Lubomirska (née Raczyńska, 1765-1847), the owner of the village of Czarnolas in central Poland, reportedly forbade the use of the surname Papiez by the peasants on her estate, replacing it with Popis $^{4}$ (Jastrzębowski 1896: 233).

The same ultimate source - Greek $\pi \dot{\alpha} \pi \tau \alpha \varsigma$ 'father' - links papież with the appellative pop, in contemporary Polish meaning 'Orthodox priest', but earlier referring to any priest or even specifically to a Catholic one (cf. Breza 2000: 339). It gave rise to a plethora of surnames: Pop 300, Popczak 94, Popczuk 24, Popczyk 1482, Popek 4196, Popków 9, Popow 315, Popowa 7, Popowczak 174, Popowicz 2101, Popowiecki 10, Popowniak 71, Popowski 2205, Popowycz 24, Popów 249, Popp 53, Poppa 7, Poppe 159, Poppek 36, Popadiak 65, Popadjak 5, Popadiuch 7, Popadiuk 97 (cf. also popadia 'an Orthodox priest's wife', popadianka 'an Orthodox priest's daughter') and perhaps several more.

In general terms, nicknames (later to become fixed surnames) associated with church hierarchy were given to people somehow connected with the church. Perhaps they tried to become priests, perhaps inaptly repeated Latin prayers after the priest, or maybe simply served at the altar (cf. Breza 2000: 250-251). More examples of that kind include Prymas 582, Prymasiak 9, Prymaszko 17 (cf. Polish appellative prymas 'primate'); Kardynat 583, Kardynalczyk 37, Kardynalski 74 (cf. kardynat 'cardinal'); Pratat 1193 (cf. prałat 'prelate'); Kanonik 94, Kanoniuk 55 - cf. kanonik 'canon (priest)'; Sufragan 3, Sufraga 10, Szufraga 1 (cf. sufragan 'suffragan bishop'); Dziekan 2356, Dziekanek 7, Dziekaniak 37, Dziekanik 16, Dziekanowicz 29, Dziekanowski 587,

3 The number after each surname refers to the number of its bearers according to Rymut (2005).

4 The surname Popis, however, was certainly not her invention, since it was in use long before her ownership of Czarnolas (in the parish of Węgleszyn in 1752 and in the parish of Kolbiel in 1753), as indicated by the data indexed in the database of the Polish Genealogical Society. 
Dziekański 1154, Dekan 2, Dekanowski 16, Dekański 152 - cf. Polish dziekan, Latin decanus 'dean (in church)'.

Of special interest due to its high frequency is the surname Biskup 6394 (cf. biskup 'bishop') and its numerous derivatives or spelling variants (Biskupek 521, Biskupiak 205, Biskupik 61, Biskupowicz 39, Biskupski 2651, Biskub 4, Biskubski 13), along with its German equivalents present in Poland (Bischof 75, Bischoff 127, Bischoffs 2), as well as Lithuanian ones (Wyskup 80, Wyskupajtis 1, Wyskupajtys 2, cf. Lithuanian appel-

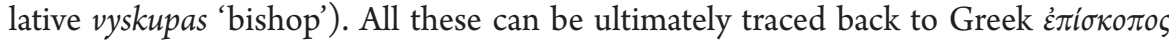
'guardian, overseer' and may have denoted a member of a bishop's entourage, someone who served in the household of a bishop, or one who was playing the part of bishop in church plays. There may have been other reasons for the emergence of that kind of surname. For instance, according to E.C. Smith, Biscop was an Old English personal name, possibly responsible for some of the instances of the contemporary English surname Bishop (cf. 1986: 132). K. Kunze (2014) emphasizes the fact that in individual cases such a name may have also originated from place names (Bischof in Schleswig-Holstein, Niedersachsen or Bayern) or a nickname for someone putting on airs, behaving as if he were a bishop.

Clergymen, especially high-ranking ones, may have been addressed with reverendus 'reverend', a term which probably motivated the Polish surname Rewerenda 37.

\section{Parish clergy}

Among the Polish surnames motivated by names of the lower-ranking clergy, a large group is motivated by appellatives with the general meaning of 'priest' (Polish $k s i a d z)$. Thus in the contemporary Polish anthroponomasticon we find Ksiadz 441, Ksiądzyk 21, Ksiądzyna 214, Ksienżyk 47, Ksieżyk 2, Księżuk 81 and Księżyk 914. A pejorative Polish word for a priest, klecha, may have also meant an organist or a church servant, and it gave rise to the names Klecha 2443, Kleszka 43, Klechta 15, Kleszyk 287 and Kleszyński 19, while its German equivalent - der Pfaffe - lies at the root of the contemporary Polish surnames Pfaf 19, Pfaff 11 and Pfaffenhausen 8 (the latter via the same-sounding toponym).

The most common Polish appellatives used in a somewhat narrower sense of 'parish priest, parson' are proboszcz and pleban (with the dialectal variant kleban). The surnames they motivate include Proboszcz 128, Proborszcz 41, Proboscz 8 and Probosz 73; an analogical German loan Propst 13, Probst 86 (cf. Old High German brobest < Latin prepositus 'president, overseer, parish priest'); Pleban 837, Plebanek 819, Plebaniak 241, Plebanik 83, Plebankiewicz 91, Plebanowicz 46, Plebańczyk 203, Plebański 320, Kleban 830, Klebaniak 18, Klebaniec 8, Klebaniuk 116, Klebankiewicz 17, Klebankowicz 4, Klebanowicz 31, Klebanowski 79, Klebański 79.

The appellative kaptan 'priest' (not necessarily Christian) is worthy of attention. First, it occasioned a considerable group of Polish surnames: Kaptan 560, Kaptanek 149, Kaptaniak 123, Kapłaniuk 18, Kapłanow 22, Kapłanowski 95, Kaptański 147, Kaplan 19. The appellative is derived from the Latin cap $(p)$ ellanus, which gave rise to numerous 
surnames in Europe, a well-known example being Caplan/Kaplan, a surname once popular among Ashkenazi Jews and today encountered in the USA. At the same time the Latin $\operatorname{cap}(p)$ ellanus in Polish developed into kapelan 'chaplain', the source of the surnames Kapelan 303, Kapelanik 15, Kapelanowicz 10, Kapelanowski 13, Kapelańczyk 192 and Kapelański 227 (cf. also the English name Chaplin of the same provenance).

The Polish appellatives wikary, wikariusz 'vicar' (from the Latin vicarius 'substitute, deputy') are today commonly understood as referring to a parochial vicar, who works in collaboration with the parish priest and helps him in his duties. However, once they referred to the priest actually performing services in a parish (on behalf of the absentee benefice holder). These appellatives gave rise to several contemporary Polish surnames: Wikary 39, Wikar 298, Wikarek 254, Wikara 3, Wikariusz 57, Wikarjusz 93, Wikarius 4, Wikarusz 1, Wikarjak 55, Wikariak 122, Wikaryjak 9, Wikarczuk 6, Wikarczyk 13, Wikarski 396, Wikaryjczak 48, Wikaryjczyk 40. They may be said to be cognates of analogous surnames in other European languages, e.g. the English Vicar, Vicars, Viccars, Vickars, Vicker, Vickers, Vickerman, Vickors, Vicarey, Vicari, Vicary, Viccari, Viccary, Vickary, Vikery, Vickrey, Vickroy or Vickery. In Ireland there is the surname Mac an Bhiocaire, in Scotland - Mac áBhiocair (both literally denoting 'son of the vicar' and anglicized McVicar or McVicker), in Italian - Vicari, in Italian and Spanish - Vicario, in Portuguese - Vigário, and in French - Vicaire (cf. TISD/Vicar, Vicary and Hanks 2003: passim).

Surnames derived from appellatives relating to various church functions also include Kaznodziej 45 - from kaznodzieja 'preacher'. Analogous Polish names of German origin (derived from der Prediger 'preacher; Black Friar', cf. predigen 'to preach', die Predigt 'sermon') are Predygier 70, Predi 15 and Predy 3. The name Orator 52 may have meant someone delivering a sermon, but also any person speaking publicly.

The names Witrykus 53 and Witryk 13 may be derived from the Latin vitricus ecclesiae 'the manager of the church finances' (cf. Breza 2000: 437). It must be borne in mind, however, that the primary meaning of the Latin vitricus was 'stepfather' (the fact that the church function is a secondary meaning is indicated e.g. by its German translation Kirchenstiefvater, a rare term used mostly in the eastern part of Germany). Alternatively, the surname Witryk may have originated from the German name Dietrich, although it would be more difficult to similarly dismiss, as derived from Dietrich, the Latinate form Witrykus.

\section{Laypeople in church service}

There are several occupational Polish surnames motivated by various church jobs customarily performed by the non-ordained. The Old Polish word światnik 'person obliged to serve in church' (cf. Rymut 2001: 586) is reflected in the names Światnik 15, Światniak 5 and Świętniak 6. The people responsible for the church or synagogue music comprise kantor or śpiewak 'singer' (Kantor 3020, Kantorczyk 91, Kantorowicz 304, Kantorowski 281, Kantorski 1370, Śpiewak 5936 and Śpiewakowski 303), as well as an organist (Organista 416, Organistka 109, Organistko 6, Organisty 12, Organiszc- 
zak 98, Organiściak 819, Organiściok 49, Organiściuk 44 - most of them denote not the musician himself, but his son). The name Psalmister 23 comes from psalmista 'author of psalms; (in Orthodox Christianity) singer of psalms', cf. psatterz 'psalter'. The names Dzwonnik 528, Dzwonowski 74, Dzwończak 42, Dzwończyk 127 and Dzwonnicki 3 are reminiscent of $d z$ won 'bell' and $d z w o n n i k$ 'bell-ringer'. The names related to the diminutive form dzwonek 'little bell' (Dzwonka 24, Dzwonkiewicz 55, Dzwonkowicz 42, Dzwonkowski 2535), as well as the surname Ottarzewski 712, derived from ottarz 'altar', may have once referred to altar boys, whose duties included ringing the consecration bells during Mass.

Finally, the appellative światynia 'temple' became the source of the names Światyński 48, Świątyniewska 1 and Świątyniowski 1. It is not quite certain if these denoted people in church service or merely those living near a church. The same uncertainty is characteristic of the names Fara 220, Farny 21 (cf. fara 'parish church') and Kościelny 3354 (cf. kościelny 'sacristan, sexton' < kościót 'church'), Kościelniak 5053, Kościelnik 265, with some more similar forms. The meaning 'sacristan, sexton', with reference to the Eastern Orthodox churches, is also carried by the appellative cerkownik - hence the surname Cerkownik 58. The word cerkiew/cerkwa 'Orthodox church' gave rise to some other surnames too: Cerkiewicz 24, Cerkiewnik 26, Cerkiewny 2, Cerkowiak 14, Cerkowniak 168, Cerkowski 45, Cyrkiewicz 3. Note that its Russian cognate, úepкoвb, refers to church as an organization rather than a building. The latter sense is covered by the appellative храм, Polish chram 'Eastern Orthodox temple' - hence the surnames Chramcow 1, Chramiec 197, Chramienko 4 (note the Ukrainian suffix), Chramienkow 3 (Russian suffix) or Chramik6 (with a Polish diminutive suffix - literally 'little Orthodox church').

\section{Monastic and reclusive life}

The center of monastic life, klasztor 'monastery', motivates the surnames Klasztor 14 and Klasztorny 59. Similar meanings lie at the root of Monasterski 195, Monastyrski 335, Monastyruk 3 and Konwent 261, though it must be noted that the Polish appellatives monaster/monastyr generally refer only to Eastern Orthodox monasteries. However, the bulk of names that refer to monastic life are reminiscent of various functions performed in a monastery.

A popular group of names stems from the appellative mnich 'monk' or its older variant monach with the same meaning (both ultimately from Latin monachus): Mnich 3087, Mnicha 1, Mnichasz 16, Mnichowicz 46, Mnichowski 128, Mnisz 4, Mniszak 91, Mniszek 114, Mniszewski 25, Mniszko 28, Monach 188, Monachiewicz 5, Monachowicz 38, Monachowski 12. Its German equivalent, Münch, became the source for Münch 45, Munch 26, Minch 48 and Mincha 14. The cognates in other European languages are still recognizable: English Monk, Monks, Monck, Monnick, Munck, Munk; Irish Minogue and Monaghan; German Mönch, Münch, Mün(n)ich, Münnig, Minnich, Mönnich, Mönnig, Mönke, Mon (ec)ke; French Moine; Spanish Monje, Monge; Portuguese Monge; Russian Мона́x, Мона́хов, Мних. The appellative zakonnik 'monk' yielded the Polish surnames 
Zakonnik 93, Zakoński 44 and Zakonek 244. The list might be enlarged by the names Inoch 48 and Inochowski 6, which according to Breza (2011:36) might be linked with the Russian инок 'monk' (today especially one who has not taken his eternal vows yet). Christian monks were not supposed to marry or have children; therefore, such a nickname must have described not a member of a monastic order but simply someone pious, God-abiding or perhaps playing the part of monk in theatrical performances. Another Latin word for a monk (also meaning 'shepherd'), mandrita, is likely to have motivated the surname Mandryto 4.

The head of a monastery, opat 'abbot', became the source of the names Opat 199, Opacki 631, Opaciak 1 and Abt 17 (from German der Abt 'abbot'), though its feminine equivalent - ksieni 'abbess' - contributed to the formation of only one name: Ksieniewicz 131. The appellative przeor 'prior' is detectable in the surnames Przeor 328, Przeorek 158, Przeorowski 4, Przeorski 345 and Prior 4. Some more monastic names are Rektor 127, Rektorek 26 - rektor once denoted not only the head of a university, but also of certain monasteries. In Franciscan Orders there is no prior but a gwardian, from which stem the names Gwardian 7, Gwardjan 14 and Gwardyan 6 (cf. Breza 2011:35). Sometimes the word senior was used to refer to a prior $^{5}$ - cf. surname Senior 28, and sometimes - perhaps in Franciscan Orders - the word kustosz $z^{6}$ (yielding the surnames Kustosz 908, Kustorz 23, Kustos 144, Kustosik 253, Kustusz 310 and Kustusch 20, see also Breza 2000: 239).

Oblacewicz 33 and Oblaciński 38 are probably linked to the appellative oblat 'oblate', from the Latin oblatus, referring to a monk who does not take vows but only makes a private promise to live according to the rule of the order; an alternative etymology indicates the Old Polish word oblata 'sacrifice, offering'. A word today forgotten is duchownik 'clergyman, priest, non-layman', also (in Eastern Orthodox churches) 'confessor', with its feminine derivative duchowniczka, denoting a nun; hence names like Duchownik 6 and perhaps several more beginning with Duchn-, Duchow-, though it is uncertain if their motivation was always religious (cf. Breza 2011:34-35).

The popular German surname Gottschalk 'God's servant' (over 15 thousand bearers in Germany) is represented in Poland in the form Gottschalk 46, but also in either distorted or Polonized orthography Gottschall 16, Gottschol 1, Gottscholl 18, Gotszalk 69, Gotszal 16, Gotszol 4, Gotszlak 1, Gotszald 18, Gotrzalk 2, Goczalk 5, Goczat 275, Goczatk 7, Goczol 22, Goczot 516 and Goczót 6 (cf. the Upper Silesian place name Goczałkowice-Zdrój, German Bad Gottschalkowitz). There is also Gottesman(n) 7 and Gott 12. However, "theophoric" surnames including the element Gott mostly come from Puritan/Pietist names (cf. e.g. Fürchtegott or Gottlieb), and as such they are

\footnotetext{
5 Cf. Stownik funkcji kościelnych tac.-pol. [Latin-Polish dictionary of church functions], http://genepedia.pl/index.php?title=S\%C5\%82ownik_funkcji_ ko\%C5\%9Bcielnych_\%C5\%82ac.-pol., accessed 14.04.2017.

6 According to SWil 569, the head of a monastery was called kustosz klasztorny, whereas kustosz kapitulny was a prelate at a cathedral where a bishop resided.
} 
patronymic, not occupational. Gottesmann may have originated as a German translation of Gabriel (cf. Breza 2000: 162).

Names of particular orders as motivation for family names include the Jesuits (Jezuita 263, Jezuit 298, Jezowit 15, Jezowitko 6, Jezuwid 9, Jezuwit 9), the Black Friars (Dominikan 4), the Camaldolese (Kameduła 230, Kamedulski 113), the Carmelites (Karmelita 790, Karmelitow 7, Karmelitów 2, Karmelicka 1) and the Pauline Fathers (Paulin 18). The Polish anthroponomasticon also includes names that relate to reclusive life: Pustelnik 3390, Pustelniak 136, Pustelny 293 (Polish pustelnik 'hermit'); Eremus 89 (Latin eremus 'hermit, recluse'). The appellative skit 'hermitage' is directly related to the surname Skit 43, formed probably by means of metonymy. The surname Schima 34 might be metonymic too (schima 'monastic vows', cf. Breza 2004: 149).

\section{Non-Catholic denominations}

Some common nouns denoting the clergy of religions other than Catholicism are traceable in Polish surnames. These include pastor 'pastor, Protestant priest', recognizable in the names Pastor 1129 and its derivatives usually referring to a pastor's son: Pastorczak 7, Pastorczyk 111, Pastorek 7, Pastorski 2. It must be noted that Pastor as a name was first attested in 1369; since the Reformation started only in 1517, the name must have originated with reference to the meaning of pasterz 'shepherd', not to a Protestant clergyman. Its Hungarian spelling variant is Pasztor 139.

Many surnames are motivated by the appellative diak/dyjak 'helper of an Orthodox priest; singer in an Orthodox church; teacher in an Orthodox parish school': Diak 204, Diakon 8, Diakoniak 7, Diakoniuk 13, Diakonow 20, Diakonowicz 11, Diakonowski 8, Diakonów 10, Diakończyk 6, Diakow 34, Diakowicz 109, Diakowski 421, Diaków 192, Diakun 131, Diaczek 61, Diaczenko 36, Diaczeńko 5, Diaczkow 2, Diaczok 7, Diaczuk 85, Diaczun 8, Diaczyk 3, Diaczyński 9, Diaczyszyn 12, Dyjak 1554, Dyjakiewicz 17, Dyjakon 17, Dyjakowski 27. The appellative wtadyka 'bishop in the Orthodox Church' gave rise to the following surnames: Wtadyka 806, Wtadykin 2, Wtadyko 91 and Wtadykowski 14.The name for an Eastern Orthodox priest, jerej, stood behind the surname Jerejski 6. Finally, Batiuszczak 8 invokes an Orthodox priest's son (cf. batiuszka - a common, colloquial term of address for an Orthodox priest in Russia or for the Russian Tsar).

In the parts of Poland once under the influence of the Ukrainian tradition, such as regions inhabited by the Lemko people or the historical region of Galicia in Eastern Europe, a priest was addressed as jegomość (Ukrainian еzомость) and his wife as jejmość (Ukrainian ïмость); hence the surname Jejmocki 14. Also of Orthodox Christian origin are the names Czerniec 617, Czerniecki 1161 and Czerniecow 11, from czerniec 'Orthodox monk' < czarny 'black'. By contrast, an unordained layperson living in a monastery would be called bielec < biaty 'white', hence the name Bielec 2241 (cf. Breza 2011:34).

The list would be incomplete without a group of surnames motivated by the appellative rabin 'rabbi': Rabin 61, Rabinek 116, Rabiniak 208, Rabinovitch 3, Rabinow 
1, Rabinowicz 16, Rabinowitz 1 and Rebe 5, as well as by Metamed 7 (cf. metamed 'melamed, i.e. teacher in a religious Jewish school'). Islam is represented by the surnames Imam 2 and Imamov 2 (the latter frequent in Russia and some former Soviet republics, like Uzbekistan). This scarcity, vis-a-vis the high frequency of e.g. the surname Imamović in Bosnia or Imamoğlu in Turkey, is understandable, considering the secondary role that Islam played in Polish history.

\section{Other names}

Lay members of the congregation are generally not immortalized in surnames, unless they performed some church function (e.g. sacristan, organist). This is hardly surprising considering that at the time of the fixation of surnames being a churchgoer was taken for granted and therefore hardly helpful in distinguishing them from the crowd. Some exceptions are Pielgrzym 33, Pielgrzymowski 37 from the appellative pielgrzym 'pilgrim'. According to Breza (2004: 141), the same meaning is carried by the surnames Bogomolec 1, Bohomolec 1 and Bohomolski 7, derived from the appellative bogomoljec 'pilgrim' 8 .

The surnames Raspopin 9 and Raspopow 17 may be linked with the appellative raspop 'a defrocked priest'.

Closely related with performing certain church functions is the appellative prebenda 'prebend', from which the name Prebendowski 16 is derived. The clergyman benefiting from the prebend is called in Polish prebendarz/prebendariusz 'prebendary' and indeed the personal name Prebendarz was attested in 1499 (cf. Rymut 2001: 295), though no such surname exists today. However, several derivatives have survived: Preweda 60, Prewencki 31, Prewendowski 112, Prewentowski 3, Prewęcki 83.

An interesting example of a surname whose contemporary shape effectively obliterated its origins is Popendyk 14, Popędyk 3. While Rymut (2001: 278) links it with the appellative poped 'fast movement, rush, impetus, drive, impulse', in our opinion the German appellative Papendieck 'priest's pond'9 serves as a more cogent explanation (alternative spellings: Pappendieck, Poppendieck, Popendieck). Considering that the name Papendi (e)ck used to be frequent in East Prussia (in $19^{\text {th }}$-century family records from Memelland it appears in the versions Papendick, Papendykin, Papendickin, Papendieck, Papendig, Papendich ${ }^{10}$ ), it might be surmised that the $a / o$ change is typical of the Lithuanian-Polish language contact - but it also might be the effect of adideation under the influence of poped.

7 Cf. http://rebrn.com/re/when-turkey-introduced-surnames-my-ancestors-picked-oneof-their-1035381/, accessed 22.06.2017. Incidentally, İmamoğlu is also a city in southern Turkey.

8 But see also bogomodlca 'one praying to God' (Arct 1920: 23).

9 Cf. http://www.onomastik.com/papendieck.php, https://de.wikipedia.org/wiki/Kennel_(Braunschweig, accessed 14.04.2017.

$\overline{10}$ Cf. http://ofb.genealogy.net/namelist.php?nachname=PAPENDIK\&ofb=memelland \&modus $=\&$ lang=de, accessed 14.04.2017. 


\section{Frequency}

Of the above-mentioned over 360 surnames, the most frequent (with a four-digit number of bearers in contemporary Poland) are the following: Biskup 6394, Śpiewak 5936, Kościelniak 5053, Popek 4196, Papież + Papierz (homophones) 3752, Pustelnik 3390, Kościelny 3354, Mnich 3087, Kantor 3020, Biskupski 2651, Dzwonkowski 2535, Klecha 2443, Dziekan 2356, Bielec 2241, Popowski 2205, Popowicz 2101, Popczyk 1482, Kantorski 1370, Pratat 1193, Czerniecki 1161, Dziekański 1154, Pastor 1129. Only the first two are included in the top thousand most frequent Polish surnames: Biskup at \#755, Śpiewak at \#814 (cf. Zawadzki 2002).

Interestingly, in countries where priests marry and have children, as in Orthodox Christianity, patronymic surnames reflecting clerical lineage are far more common. Thus, the three most frequent surnames in 2013 in Romania were Popa 'priest', Popescu

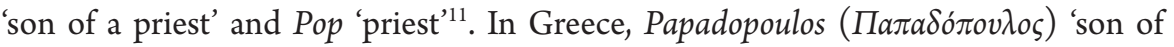

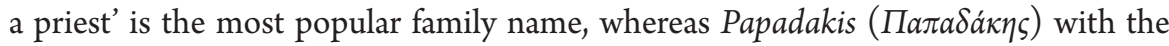
same meaning, as well as Papantoniou (Пa $a v \tau \omega v i o v)$ 'son of priest Antonios', oscillate around \#10 in frequency. The Russian Пonó 6 'son of a priest' was in 2005 the $4^{\text {th }}$ most common surname in that country. The surname Popa 'priest' in 2007 ranked $9^{\text {th }}$ in Moldova ${ }^{12}$, with 3373 families of that name.

Nevertheless, not only in predominantly Orthodox countries are certain such surnames relatively frequent. The surname Pap 'priest' occupies $12^{\text {th }}$ position on the frequency list in Hungary (cf. Farkas 2015: 131), and in 2008 the name Popović 'son of priest', with 6797 bearers, ranked $27^{\text {th }}$ in Croatia ${ }^{13}$.

\section{References}

Arct - Krasnowolski, A. and W. Niedźwiedzki. Abt. 1920. M. Arcta stownik staropolski [M. Arct's Old Polish dictionary]. Warszawa: Wydawnictwo M. Arcta.

Breza, E. 2000. Nazwiska Pomorzan: pochodzenie i zmiany [Names of Pomeranians: their origin and changes]. Gdańsk: Wydawnictwo Uniwersytetu Gdańskiego.

Breza, E. 2004. Nazwiska od apelatywów cerkiewnych [Surnames derived from Orthodox Church appellatives]. In Pogranicza: kontakty kulturowe, literackie, językowe, L. Dacewicz (ed.), 139-154. Białystok: Wydawnictwo Uniwersytetu w Białymstoku.

Breza, E. 2011. Nazwiska obywateli polskich, wywodzące się od wyrazów nazywających duchownych [Surnames of Polish citizens derived from words naming the clergy]. Jezzykszkoła - religia 6: 32-48.

Farkas, T. 2015. The Most Frequent Hungarian Surnames. A Study of Some Aspects of Contrastive Surname Typology. In Proceedings of the Third International Conference on Onomastics "Name and Naming": Conventional / Unconventional in Onomastics, O. Felecan (ed.), 122-136. Baia Mare: Mega/Argonaut.

Hanks, P. 2003. Dictionary of American Family Names. Oxford: Oxford University Press.

\footnotetext{
11 http://www.name-statistics.org/ro/numedefamiliecomune.php, accessed 17.04.2017.

12 http://nume.casata.md/, accessed 17.04.2017.

13 https://en.wikipedia.org/wiki/List_of_most_common_surnames_in_ Europe\#Croatia, accessed April 17, 2017.
} 
Jastrzębowski, S. 1896. Czarnolas i Policzna. Notatki etnograficzne [An ethnographer's notes on the villages of Czarnolas and Policzna in Mazovia, Poland]. Wista 6 (2): 225-244.

Kunze, K. 2014. Viele Nachnamen gehen auf Berufe des Mittelalters zurück. Woher aber kommen Nachnamen wie Bischoff, Probst oder Papst? https://www.wissenschaft-im-dialog.de (accessed 09.04.2017).

Phipps, W.E. 2004. Clerical Celibacy: The Heritage. New York - London: The Continuum.

Rymut, K. 1999. Nazwiska Polaków: Stownik historyczno-etymologiczny I [Surnames of Poles: a historical-etymological dictionary]. Kraków: IJP PAN.

Rymut, K. 2001. Nazwiska Polaków: Stownik historyczno-etymologiczny II. Kraków: DWN.

Rymut, K. 2005. Stownik nazwisk używanych w Polsce na początku XXI wieku. Wydanie drugie poprawione [Dictionary of surnames used in Poland at the turn of the $21^{\text {st }}$ century, second edition, revised]. Kraków: IJP PAN. CD-ROM.

Smith, E.C. 1986. American Surnames. Baltimore: Genealogical Publishing Co.

SSNO - Stownik staropolskich nazw osobowych [Dictionary of Old Polish personal names]. W. Taszycki (ed.). 1965-1987. Wrocław: Zakład Narodowy im. Ossolińskich.

SWil - Stownik języka polskiego [Dictionary of Polish], compiled by A. Zdanowicz et al. 1861. Wilno: M. Orgelbrand.

TISD - The Internet Surname Database, http://www.surnamedb.com/Surname (accessed 09.04.2017).

Tomczak, L. 1992. Nieoficjalne antroponimy jako przejaw zachowań językowych w społeczności wiejskiej Smęgorzowa (Tarnowskie) [Unofficial anthroponyms as an aspect of language behaviour in the rural community of Smęgorzów in Tarnów Voyvodeship]. In Język a kultura 6: Polska etykieta językowa, M. Marcjanik and J. Anusiewicz (eds.), 127-132. Wrocław: „Wiedza o kulturze”.

Zawadzki, J.M. 2002. 1000 najpopularniejszych nazwisk $w$ Polsce [1000 most frequent surnames in Poland]. Warszawa: Bertelsmann. 